\title{
Mortality of workers certified by pneumoconiosis medical panels as having asbestosis
}

\author{
G BERRY \\ From the MRC Pneumoconiosis Unit, Llandough Hospital, Penarth, South Glamorgan CF6 $1 X W$, UK
}

\begin{abstract}
A mortality study has been carried out at the London, Cardiff, or Swansea Pneumoconiosis Medical Panels between 1952 and 1976 on people certified as suffering from asbestosis. The main analysis was of 665 men, 283 of whom had died. Of the deaths, 39\% were from lung cancer, $9 \%$ mesothelioma, and $20 \%$ asbestosis. The observed mortality was compared with expectation based on the death rates for England and Wales. For all causes the observed number of deaths was 2.6 times expectation and for lung cancer $9 \cdot 1$ times expectation. After 10 years from first certification half of the men had died compared with an expectation of one in four. The excess death rates were apparent in the first year after certification and were still operating after 10 years on those who survived until then. The main factor influencing the mortality was the clinical state of the men at the time of certification, as indicated by the percentage disability awarded; the excess lung cancer rate and the mesothelioma and asbestosis rates all increased with percentage disability. Those awarded only $10 \%$ or $20 \%$ benefit were still at risk from all the three asbestos-related causes. For a man certified at age 55 it was estimated that his life expectation would be reduced by 3,5, 8, or 12 years according to whether his rate of disablement benefit was $10 \%, 20 \%, 30 \%$ or $40 \%$, or $50 \%$ or more respectively.
\end{abstract}

In Britain workers may be awarded disablement benefit under the Industrial Injuries Acts if a pneumoconiosis medical board considers that they are suffering from a prescribed disease as a result of occupational exposure to asbestos. The prescribed diseases are asbestosis and mesothelioma. Lung cancer occurring in the presence of asbestosis is regarded as resulting from asbestosis and therefore attracts benefit. A claim may be made during life or by a dependant at death. If a claim is successful during life disablement benefit is awarded as a percentage between 10 and 100 according to the degree of disablement. Those certified are regularly reexamined and the benefit may be increased.

According to $\mathrm{McVittie}^{1}$ the pneumoconiosis medical boards diagnose asbestosis if there is a history of adequate exposure and at least two of the following four conditions are present: basal rales, finger clubbing, radiological abnormality, and impairment of lung function. This view is still supported by DHSS ${ }^{2}$ except that finger clubbing is considered too late a sign to influence diagnosis.

The number of cases certified with asbestosis in

Received 20 March 1980

Accepted 2 May 1980
Britain was, on average, 35 a year during 1958-62, 94 a year during 1963-7, 122 a year during 1968-72, and 138 a year during $1973-6 .^{3}$

Very little has been published on the mortality after certification. McVittie ${ }^{1}$ followed up 247 workers certified during 1955-63 and of 59 deaths, $21(36 \%)$ were due to lung cancer, $17(29 \%)$ to asbestosis, and $3(5 \%)$ to mesothelioma. The Department of Employment and Productivity, ${ }^{4}$ reporting on 430 cases certified between 1956 and 1965 , concluded that the "mortalities are about two or three times that of the general male population of equivalent ages." McVitties' study was of cases at the London, Manchester, Newcastle, and Sheffield Pneumoconiosis Medical Panels and the second study was of cases at four panels that were unnamed but probably the same as in McVittie's study.

In this paper those people who were first awarded benefit for asbestosis during 1952-76 at the London, Cardiff, or Swansea Panels were followed up, and the observed mortality, from all causes and for separate causes, was compared with that of the general population. Cases where the benefit was first awarded for mesothelioma are not included. A preliminary report of this study has previously been given. ${ }^{5}$

130 


\section{Methods}

Records were made available in anonymous form for cases first certified during 1952-76 at the London, Cardiff, and Swansea Pneumoconiosis Medical Panels. The cases at Cardiff also included those certified at the Bristol Panel, which is now closed. The London Panel covers people living in South and South-east England, including the Greater London area and East Anglia, and the Cardiff and Swansea Panels cover the whole of Wales and South-west England. Within the area covered by the London Panel there are factories manufacturing asbestos products, and the Cardiff Panel covers the Devonport naval dockyard.

Only 24 cases had been certified in Swansea, and they have been combined with the Cardiff cases. The number of cases whose files were examined and the total number of cases are given in table 1 by panel and year. Out of a total of 756 cases the files of 39 were not available for various reasons. Most of the missing files were for cases certified before 1966.

Table 1 Files examined and total number of cases

\begin{tabular}{|c|c|c|c|c|}
\hline \multirow[t]{2}{*}{ Years* } & \multicolumn{2}{|c|}{ Cardiff and Swansea } & \multicolumn{2}{|l|}{ London } \\
\hline & \multicolumn{2}{|c|}{$\begin{array}{l}\text { Examined/total } \\
(\% \text { examined })\end{array}$} & \multicolumn{2}{|c|}{$\begin{array}{l}\text { Examined/total } \\
(\% \text { examined })\end{array}$} \\
\hline $\begin{array}{l}1952-55 \\
1956-60 \\
1961-65 \\
1966-70 \\
1971-76\end{array}$ & $\begin{array}{c}2 / 2 \\
2 / 3 \\
12 / 17 \\
135 / 139 \\
129 / 130\end{array}$ & $\begin{array}{r}(100) \\
(67) \\
(71) \\
(97) \\
(99)\end{array}$ & $\begin{array}{c}44 / 54 \\
40 / 47 \\
82 / 86 \\
128 / 132 \\
143 / 146\end{array}$ & $\begin{array}{l}(81) \\
(85) \\
(95) \\
(97) \\
(98)\end{array}$ \\
\hline Total & $280 / 291$ & (96) & $437 / 465$ & (94) \\
\hline
\end{tabular}

*In this table year relates to when case was entered into central records, which in some cases was year after diagnosis.

The data extracted included the date of first certification, the diagnosis, the percentage award, coded smoking habits, and an occupational history. For those who had died the date of death was extracted and a coded "most likely" cause of death as assessed by the pathologist and panel. The others were assumed to be alive up to a month before the data were extracted-that is, up to May 1977 for $90 \%$ of the London cases, August 1978 for the other $10 \%$, and April 1978 for the Cardiff and Swansea cases.

The observed numbers of deaths were compared with the numbers expected, which were calculated by the "man-years" method ${ }^{6}$ using the age-, period-, and sex-specific death rates for England and Wales. Excess mortality was tested by treating the observed number of deaths as a Poisson variable, and comparisons of excess mortality between groups, and after allowing for other grouping factors, were carried out using a maximum-likelihood method.

\section{Results}

The number of cases in the study are given in table 2 grouped by panel, sex, and the reason for certification; all the cases at Cardiff and Swansea were men.

Table 2 Reasons for certification

\begin{tabular}{|c|c|c|c|c|c|}
\hline & \multirow{2}{*}{ Cardiff } & \multirow[t]{2}{*}{ Swansea } & \multicolumn{2}{|c|}{ London } & \multirow[t]{2}{*}{ Total } \\
\hline & & & Men & Women & \\
\hline \multirow{2}{*}{$\begin{array}{l}\text { Certified at death } \\
\text { Asbestosis } \\
\text { Lung cancer and } \\
\quad \text { asbestosis }\end{array}$} & $\begin{array}{r}2 \\
253\end{array}$ & $\begin{array}{r}3 \\
19\end{array}$ & $\begin{array}{r}5 \\
393\end{array}$ & $\begin{array}{c}0 \\
21\end{array}$ & $\begin{array}{c}10 \\
686\end{array}$ \\
\hline & 2 & 1 & 17 & 1 & 21 \\
\hline Total & 257 & 23 & 415 & 22 & 717 \\
\hline
\end{tabular}

There were four groups:

(a) the 10 men certified at death;

(b) the 21 cases certified in life as suffering from lung cancer with asbestosis;

(c) the 665 men certified as suffering from asbestosis;

(d) the 21 women with asbestosis.

The analysis was restricted to those diagnosed in life as suffering from asbestosis and with no tumour observed when first certified-that is, to groups $(c)$ and $(d)$.

\section{ASBESTOSIS CASES}

Of 686 cases diagnosed as asbestosis, 295 have died. The cases are shown by year of certification in table 3.

Table 3 Year of certification of asbestosis cases. (Numbers in parentheses are deaths)

\begin{tabular}{lrrrrrrrr}
\hline $\begin{array}{l}\text { Year of } \\
\text { certification }\end{array}$ & \multicolumn{2}{l}{$\begin{array}{l}\text { Cardiff and } \\
\text { Swansea }\end{array}$} & \multicolumn{2}{l}{ London } & \multicolumn{3}{c}{ Total } \\
\cline { 3 - 7 } & & \multicolumn{2}{l}{ Men } & \multicolumn{3}{c}{ Women } \\
\hline $1952-55$ & 2 & $(1)$ & 39 & $(31)$ & 5 & $(3)$ & 46 & $(35)$ \\
$1956-60$ & 2 & $(1)$ & 34 & $(30)$ & 5 & $(4)$ & 41 & $(35)$ \\
$1961-65$ & 11 & $(6)$ & 73 & $(55)$ & 7 & $(5)$ & 91 & $(66)$ \\
$1966-70$ & 134 & $(54)$ & 119 & $(49)$ & 4 & $(0)$ & 257 & $(103)$ \\
$1971-76$ & 123 & $(32)$ & 128 & $(24)$ & 0 & & 251 & $(56)$ \\
Total & 272 & $(94)$ & 393 & $(189)$ & 21 & $(12)$ & 686 & $(295)$ \\
\hline
\end{tabular}

Figure 1 shows the distribution of initial disablement benefit; most were $10 \%$ or $20 \%$. There was an association between benefit and subsequent mortality; the proportions dead were $34 \%$ of those awarded $10 \%$ or $20 \%, 60 \%$ of those awarded $30 \%$ or $40 \%$, and $77 \%$ of those awarded $50 \%$ or more.

The cases were divided into two occupational groups. The first group consisted of those doing insulation work, such as lagging or spraying (laggers), and the other group consisted of the remainder 


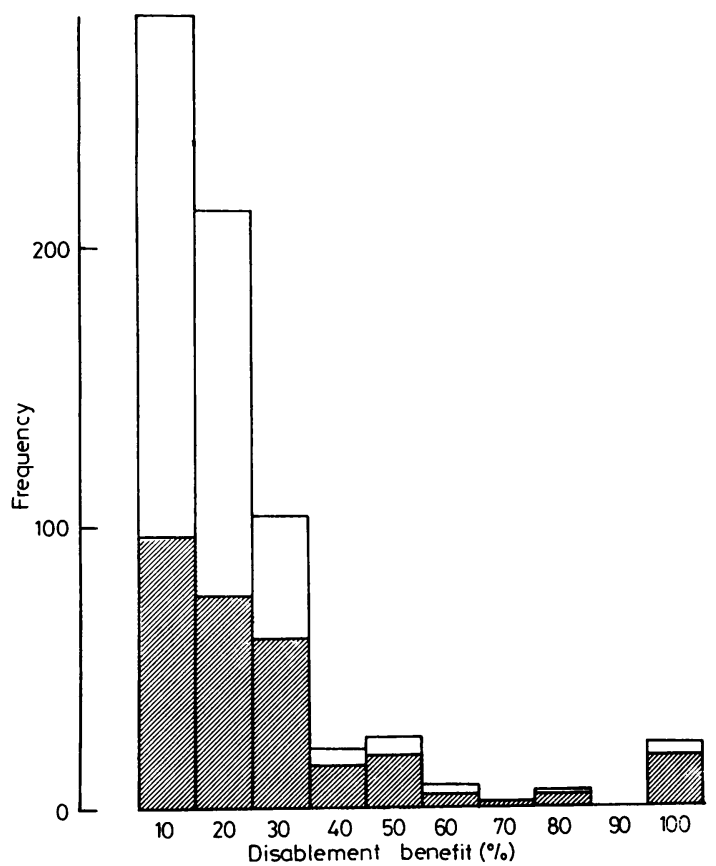

Fig 1 Distribution of disablement benefit at first certification for men and women with asbestosis. Shaded areas are deaths.

(table 4). For the London cases, $54 \%$ of the nonlaggers have died compared with $41 \%$ of the laggers, but this difference partly resulted from the laggers, on average, being certified more recently than the non-laggers-for instance, $67 \%$ of the laggers were certified after 1965 compared with $59 \%$ of the nonlaggers. For the Cardiff cases there was no difference between occupations in the proportion dead; $34 \%$ of laggers and $35 \%$ of non-laggers.

Table 4 Attributable occupation of asbestosis cases. (Numbers in parentheses are deaths)

\begin{tabular}{lllllllll}
\hline Occupation & \multirow{2}{*}{$\begin{array}{l}\text { Cardiff and } \\
\text { Swansea }\end{array}$} & \multicolumn{2}{l}{ London } & \multicolumn{3}{c}{ Total } \\
\cline { 3 - 7 } & & & Men & \multicolumn{3}{c}{ Women } \\
\hline Lagging & 112 & $(38)$ & 187 & $(77)$ & 0 & & 299 & $(115)$ \\
Non-laggers & 160 & $(56)$ & 206 & $(112)$ & 21 & $(12)$ & 387 & $(180)$ \\
\hline
\end{tabular}

Figure 2 gives the ages at certification. The mean ages were at the Cardiff and Swansea Panels 57 for the men, and at the London Panel 54 for the men and 50 for the women. Most men were certified before the normal retirement age of 65 and all the women before their normal retirement age of 60 .

Table 5 gives the causes for the 295 deaths. Where asbestosis is noted then this indicates that the

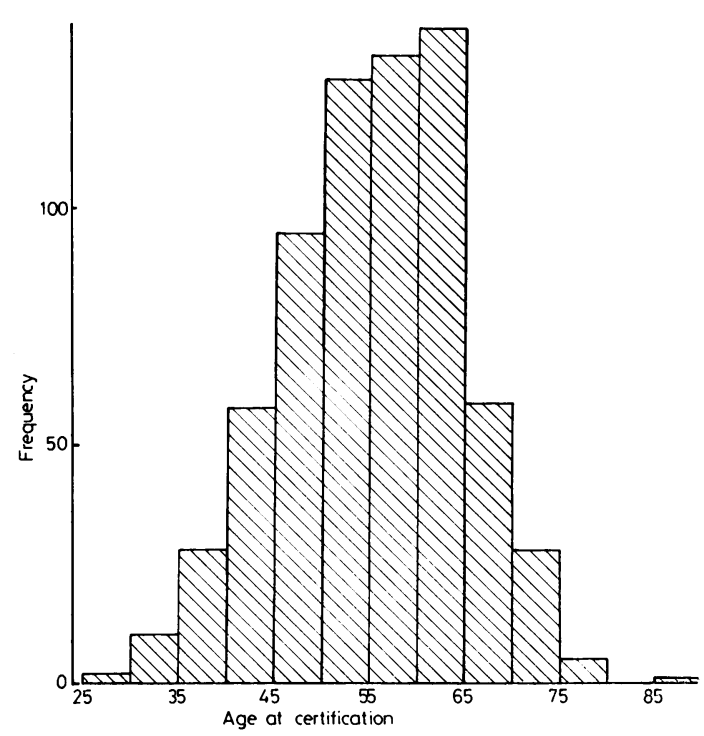

Fig 2 Distribution of age at first certification for men and women with asbestosis.

disease contributed to death and was not just present. For example, $112(59 \%)$ of the London dead men had asbestos recorded as contributing to death, but the presence of asbestosis at necropsy was recorded in $157(83 \%)$. The ages at death are given in fig 3; the means were at Cardiff and Swansea 65 , at London 61 for men and 60 for women.

Table 5 Causes of death of asbestosis cases

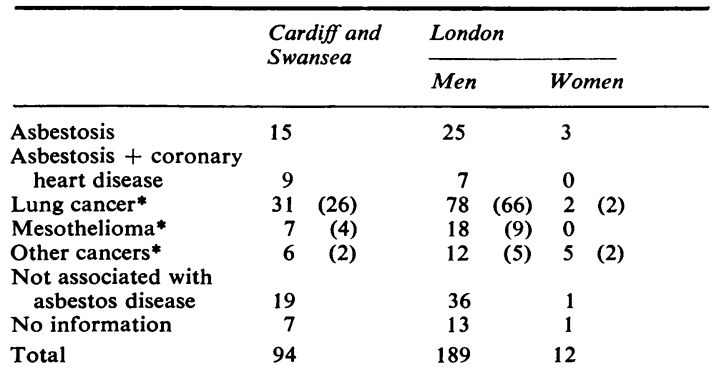

*Figures in parentheses are numbers of deaths in which it was recorded that asbestosis contributed to death but cancer was main cause.

\section{Comparison of observed and expected mortality for} men with asbestosis

Table 6 gives the mortality of men by time since certification. At both panels the death rates were much higher than for the general population, and most of the excess at London and all of the excess at Cardiff occurred as a result of lung cancer, meso- 


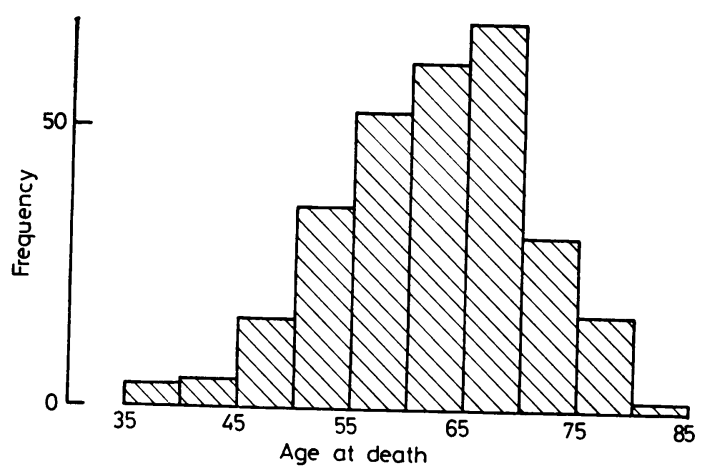

Fig 3 Distribution of age at death for men and women with ashestosis.

thelioma, and asbestosis. The excess mortality was higher for the London cases than for those at Cardiff and Swansea at all durations of follow-up, both for all deaths and for those due to lung cancer. In total the death rate for all causes was three times expectation at London and twice expectation at Cardiff; for lung cancer the death rates were 12 and six times expectation respectively. The mesothelioma rate was also higher at London than Cardiff, seven compared with four per 1000 subject-years, but this difference was not significant. Deaths due to asbestosis were at a similar rate for the two panels. The excess death rates were apparent in the first year after certification at both panels; at London 33 deaths in the first year included 12 lung cancers and five mesotheliomas, and at Cardiff 18 deaths included seven lung cancers and three mesotheliomas. Men who survived for 10 years after certification were still at excess risk at this time, particularly from lung cancer, although there was a suggestion that the excess death rate from all causes declined after 10 years.

Eight of the other cancers at London were of the gastrointestinal tract; this was higher than the expectation of 4.8 but could have arisen by chance. At Cardiff there were two or three cancers of the gastrointestinal tract, which was less than the expectation of 3.9 .

In table 7 mortality is tabulated against the initial percentage award. There was a clear increase in the excess death rates for all deaths and lung cancer, with increasing benefit. The same was also true of mesothelioma and asbestosis if these are expressed in terms of the number of subject-years of follow-up. Even so those awarded only $10 \%$ or $20 \%$ were at excess risk of death from lung cancer, mesothelioma, and asbestosis, although at Cardiff there was no evidence of an overall excess death rate for those with $10 \%$ benefit. The higher death rates at London compared with Cardiff occurred mainly in the $10 \%$ and $20 \%$ compensation groups.

Figure 4 shows the survival of all the men during the first 20 years after certification calculated by life-table methods. The observed survival is shown in three groups according to the initial disablement benefit. Also shown is the expected survival if the death rates of men in England and Wales had applied. The excess mortality and its association with disablement benefit is apparent. After 10 years

Table 6 Observed and expected mortality of men by time since certification

\begin{tabular}{|c|c|c|c|c|c|c|c|c|c|c|c|c|}
\hline & \multicolumn{2}{|c|}{0.5 years } & \multirow[b]{2}{*}{ Obs/Exp } & \multicolumn{2}{|c|}{5.10 years } & \multirow[b]{2}{*}{ Obs/Exp } & \multicolumn{2}{|c|}{$>10$ years } & \multirow[b]{2}{*}{ Obs/Exp } & \multirow{2}{*}{$\begin{array}{l}\text { Total } \\
\text { Obs }\end{array}$} & \multirow[b]{2}{*}{$\operatorname{Exp}$} & \multirow[b]{2}{*}{ Obs/Exp } \\
\hline & Obs & $\operatorname{Exp}$ & & Obs & $\operatorname{Exp}$ & & Obs & $\operatorname{Exp}$ & & & & \\
\hline \multicolumn{13}{|c|}{ London } \\
\hline No/subject-years & \multirow{2}{*}{\multicolumn{2}{|c|}{$393 / 1473$}} & & \multirow{2}{*}{\multicolumn{2}{|c|}{$212 / 712$}} & & \multirow{2}{*}{\multicolumn{2}{|c|}{$74 / 338$}} & & \multirow{2}{*}{\multicolumn{2}{|c|}{$393 / 2523$}} & \\
\hline $\begin{array}{l}\text { Cause of death } \\
\text { All causes }\end{array}$ & & & & & & & & & & & & \\
\hline & $\begin{array}{r}105 * * * \\
39 * * *\end{array}$ & $28 \cdot 0$ & $3 \cdot 7$ & $58 * * *$ & $18 \cdot 5$ & $3 \cdot 1$ & $26 * *$ & 13.4 & $1 \cdot 9$ & $189^{* * *}$ & $59 \cdot 8$ & $3 \cdot 2$ \\
\hline & $\begin{array}{l}39^{* * * *} \\
11\end{array}$ & $3 \cdot 3$ & $11 \cdot 8$ & $27^{* * *}$ & $2 \cdot 1$ & $12 \cdot 9$ & $12 * * *$ & $1 \cdot 4$ & $8 \cdot 6$ & $78 * * *$ & $6 \cdot 7$ & $11 \cdot 6$ \\
\hline $\begin{array}{l}\text { Mesothelioma } \\
\text { Other cancers }\end{array}$ & $\begin{array}{r}11 \\
4\end{array}$ & $\overline{4} \cdot 0$ & $\overline{1}$ & 5 & - & - & 2 & - & $\overline{17}$ & 18 & - & - \\
\hline & $\begin{array}{r}4 \\
19\end{array}$ & $4 \cdot 0$ & $1 \cdot 0$ & 5 & $2 \cdot 6$ & $1 \cdot 9$ & 3 & $1 \cdot 8$ & $1 \cdot 7$ & 12 & $8 \cdot 4$ & $1 \cdot 4$ \\
\hline \multirow{2}{*}{$\begin{array}{l}\text { Other causes (or no } \\
\text { information) }\end{array}$} & 10 & - & 一 & 9 & - & - & 4 & - & - & 32 & 一 & 一 \\
\hline & $32^{*}$ & $20 \cdot 7$ & $1 \cdot 5$ & 12 & $13 \cdot 8$ & 0.9 & 5 & $10 \cdot 2$ & $0 \cdot 5$ & 49 & $44 \cdot 7$ & $1 \cdot 1$ \\
\hline \multicolumn{13}{|c|}{ Cardiff and Swansea } \\
\hline $\begin{array}{l}\text { No/subject-years } \\
\text { Cause of death }\end{array}$ & \multicolumn{2}{|c|}{$272 / 1064$} & & \multicolumn{2}{|c|}{$156 / 492$} & & \multicolumn{2}{|l|}{$44 / 86$} & & \multirow{2}{*}{\multicolumn{2}{|c|}{$272 / 1642$}} & \\
\hline All causes & $53 * * *$ & $28 \cdot 8$ & $1 \cdot 8$ & $36^{* * *}$ & $17 \cdot 0$ & $2 \cdot 1$ & 5 & $3 \cdot 0$ & $1 \cdot 7$ & $94 * * *$ & & $1 \cdot 9$ \\
\hline Lung cancer & $17 * * *$ & $3 \cdot 3$ & $5 \cdot 2$ & $13 * * *$ & $1 \cdot 8$ & $7 \cdot 2$ & 1 & $0 \cdot 3$ & $3 \cdot 3$ & $31 * * *$ & $5 \cdot 3$ & $5 \cdot 8$ \\
\hline Mesothelioma & 6 & - & - & 1 & - & - & 0 & - & - & 7 & 一 & - \\
\hline Other cancers & 3 & $4 \cdot 0$ & $0 \cdot 7$ & 3 & $2 \cdot 3$ & $1 \cdot 3$ & $\mathbf{0}$ & 0.4 & $0 \cdot 0$ & 6 & $6 \cdot 7$ & 0.9 \\
\hline $\begin{array}{l}\text { Asbestosis } \\
\text { Other causes (or no }\end{array}$ & 9 & 一 & - & 12 & 一 & - & 3 & - & - & 24 & 一 & - \\
\hline information) & 18 & $21 \cdot 5$ & $0 \cdot 8$ & 7 & $12 \cdot 9$ & $0 \cdot 5$ & 1 & $2 \cdot 3$ & $0 \cdot 4$ & 26 & $36 \cdot 8$ & 0.7 \\
\hline
\end{tabular}

$* \mathrm{p}<0.05 \quad *{ }^{*} \mathrm{p}<0.01 \quad * * * \mathrm{p}<0.001$.

Significance of excess mortality (one-sided test). 
Table 7 Observed and expected mortality of men by initial disablement benefit (\%)

\begin{tabular}{|c|c|c|c|c|c|c|c|c|c|c|c|c|}
\hline & $\begin{array}{l}10 \\
O b s\end{array}$ & $\operatorname{Exp}$ & Obs/Exp & $\begin{array}{l}20 \\
O b s\end{array}$ & $\operatorname{Exp}$ & Obs/Exp & $\begin{array}{l}30 \text { or } 40 \\
\text { Obs }\end{array}$ & $\operatorname{Exp}$ & $O b s / E x p$ & $\begin{array}{l}>50 \\
\text { Obs }\end{array}$ & $\operatorname{Exp}$ & Obs/Exp \\
\hline \multicolumn{13}{|c|}{ London } \\
\hline $\begin{array}{l}\text { No/subject-years } \\
\text { Cause of death }\end{array}$ & \multicolumn{3}{|c|}{$156 / 1294$} & $122 / 667$ & & & \multicolumn{3}{|l|}{$75 / 418$} & \multicolumn{2}{|l|}{$40 / 144$} & \\
\hline All causes & $71^{* * *}$ & $30 \cdot 2$ & $2 \cdot 4$ & $40 * * *$ & $14 \cdot 1$ & $2 \cdot 8$ & $42 * * *$ & $11 \cdot 9$ & $3 \cdot 5$ & $36 * * *$ & 3.6 & $10 \cdot 0$ \\
\hline Lung cancer & $30 * * *$ & $3 \cdot \overline{3}$ & $9 \cdot 1$ & $21 * * *$ & $1 \cdot 7$ & $12 \cdot 4$ & $17^{* * *}$ & $1 \cdot 3$ & $13 \cdot 1$ & $10 * * *$ & 0.4 & $25 \cdot 0$ \\
\hline Mesothelioma & 9 & - & - & 1 & - & - & 3 & - & 一 & 5 & - & - \\
\hline Asbestosis & 10 & - & - & 5 & - & - & 7 & - & - & 10 & - & - \\
\hline \multicolumn{13}{|c|}{ Cardiff and Swansea } \\
\hline No/subject-years & \multirow{2}{*}{\multicolumn{3}{|c|}{$122 / 740$}} & $84 / 558$ & & & $47 / 274$ & & & $19 / 70$ & & \\
\hline Cause of death & & & & & & & & & & & & \\
\hline All causes & 22 & $20 \cdot 1$ & $1 \cdot 1$ & $30 * * *$ & $16 \cdot 8$ & $1 \cdot 8$ & $31^{* * *}$ & $8 \cdot 5$ & $3 \cdot 6$ & $11 * * *$ & $3 \cdot 3$ & $3 \cdot 3$ \\
\hline Lung cancer & 5 & $2 \cdot 2$ & $2 \cdot 3$ & $7 * *$ & $1 \cdot 9$ & $3 \cdot 7$ & $14 * * *$ & $1 \cdot 0$ & $14 \cdot 0$ & $5 * * *$ & $0 \cdot 3$ & $16 \cdot 7$ \\
\hline Mesothelioma & 0 & - & - & 1 & - & - & 3 & - & - & 3 & - & - \\
\hline Asbestosis & 7 & - & - & 10 & - & - & 5 & - & - & 2 & - & - \\
\hline
\end{tabular}

$* *$ * $p<0.001$.

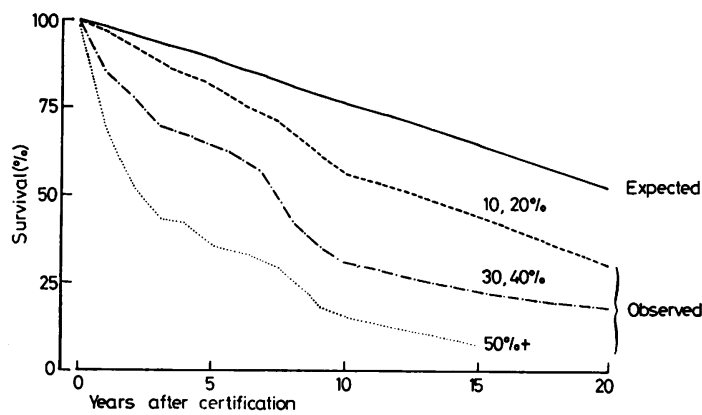

Fig 4 Survival after certification of men with asbestosis. Relationships were obtained by life table methods. The expected were calculated using death rates for England and Wales. Observed survivals are shown for initial disablement benefits of 10 or $20 \%, 30$ or $40 \%$, and $50 \%$ or more.

only one man in four would be expected to be dead but for those awarded benefit of $10 \%$ or $20 \%$ almost one-half were dead, for $30 \%$ or $40 \%$ benefit twothirds, and for $50 \%$ or more benefit five-sixths.

In table 8 the laggers are compared with the nonlaggers for each panel separately. At London the non-laggers experienced higher excess mortality than the laggers, mainly for lung cancer, but there was no such difference at Cardiff. These proportions of deaths due to mesothelioma were similar for non-laggers as for laggers.

In table 9 the effect of year of certification is examined for London cases only and restricting the follow-up to the first 10 years after certification. The prognosis was worse for those first certified before 1966 but still poor for those certified more recently.

It was mentioned earlier that the laggers at London had, on average, been certified more recently than the non-laggers. An analysis was made to see if this influenced the results given in tables 8 and 9. It was found that for lung cancer the differences noted in the two tables were a consequence of a rate 17 times expectation for the non-laggers certified before 1966 . By contrast the laggers certified before 1966 and both occupational groups certified after 1965 had a lung cancer rate of eight to 11 times expectation.

The influence of age at first certification was examined by dividing the men at each panel into two groups: under or over 55 (table 10). The excess mortality, for all causes and lung cancer, occurred

Table 8 Observed and expected mortality of men by occupation

\begin{tabular}{|c|c|c|c|c|c|c|c|c|c|c|c|c|}
\hline & \multicolumn{6}{|l|}{ London } & \multicolumn{6}{|c|}{ Cardiff and Swansea } \\
\hline & $\begin{array}{l}\text { Laggers } \\
\text { Obs }\end{array}$ & $\operatorname{Exp}$ & Obs/Exp & $\begin{array}{l}\text { Non-lag } \\
\text { Obs }\end{array}$ & $\begin{array}{l}\text { gers } \\
\text { Exp }\end{array}$ & Obs/Exp & $\begin{array}{l}\text { Laggers } \\
\text { Obs }\end{array}$ & $\operatorname{Exp}$ & $O b s / E x p$ & $\begin{array}{l}\text { Non-lag } \\
\text { Obs }\end{array}$ & $\begin{array}{l}\text { gers } \\
\text { Exp }\end{array}$ & Obs/Exp \\
\hline $\begin{array}{l}\text { No/subject-years } \\
\text { Cause of death }\end{array}$ & \multicolumn{3}{|l|}{$187 / 1239$} & \multicolumn{3}{|c|}{$206 / 1285$} & \multicolumn{3}{|l|}{$112 / 748$} & \multicolumn{3}{|l|}{$160 / 893$} \\
\hline All causes & $77 * * *$ & $28 \cdot 5$ & $2 \cdot 7$ & $112 * * *$ & $31 \cdot 4$ & $3 \cdot 6$ & $38 * * *$ & $18 \cdot 6$ & $2 \cdot 0$ & $56^{* * *}$ & $30 \cdot 2$ & 1.9 \\
\hline Lung cancer & $28 * * *$ & $3 \cdot 2$ & $8 \cdot 8$ & $50 * * *$ & $3 \cdot 5$ & $14 \cdot 3$ & $15^{* * *}$ & $2 \cdot 1$ & $7 \cdot 1$ & $16 * * *$ & $3 \cdot 2$ & $5 \cdot 0$ \\
\hline Mesothelioma & 7 & - & - & 11 & - & - & 3 & - & - & 4 & - & - \\
\hline Asbestosis & 17 & 一 & 一 & 15 & - & 一 & 13 & - & - & 11 & - & 一 \\
\hline
\end{tabular}

$* * * \mathrm{p}<0.001$. 
Table 9 Observed and expected mortality by year of certification within 10 years of certification for London men

\begin{tabular}{lllllll}
\hline & $\begin{array}{l}\text { Before } 1966 \\
\text { Obs }\end{array}$ & Exp & Obs/Exp & $\begin{array}{l}\text { After } 1965 \\
\text { Obs }\end{array}$ & Exp & Obs/Exp \\
\hline $\begin{array}{l}\text { No/subject-years } \\
\text { Cause of death }\end{array}$ & $146 / 983$ & & & $247 / 1202$ & & \\
$\quad \begin{array}{lll}\text { All causes } \\
\text { Lung cancer }\end{array}$ & $90^{* * *}$ & $19 \cdot 9$ & $4 \cdot 5$ & $73^{* * *}$ & $26 \cdot 6$ & $2 \cdot 7$ \\
$\begin{array}{l}\text { Mesothelioma } \\
\text { Asbestosis }\end{array}$ & $35^{* * *}$ & $2 \cdot 3$ & $15 \cdot 2$ & $31^{* * *}$ & $3 \cdot 1$ & $10 \cdot 0$ \\
\hline
\end{tabular}

${ }^{* * *} \mathrm{p}<0.001$

Table 10 Observed and expected mortality of men by age at certification

\begin{tabular}{|c|c|c|c|c|c|c|c|c|c|c|c|c|}
\hline & \multicolumn{6}{|c|}{ London } & \multicolumn{6}{|c|}{ Cardiff and Swansea } \\
\hline & $\begin{array}{l}<55 \\
O b s\end{array}$ & $\operatorname{Exp}$ & Obs/Exp & $\begin{array}{l}>55 \\
O b s\end{array}$ & $\operatorname{Exp}$ & Obs/Exp & $\begin{array}{l}<55 \\
\text { Obs }\end{array}$ & $\operatorname{Exp}$ & Obs/Exp & $\begin{array}{l}>55 \\
O b s\end{array}$ & Exp & Obs/Exp \\
\hline $\begin{array}{l}\text { No/subject-years } \\
\text { Cause of death }\end{array}$ & \multicolumn{3}{|c|}{$206 / 1558$} & \multicolumn{3}{|l|}{$187 / 965$} & \multicolumn{3}{|l|}{$99 / 715$} & \multicolumn{2}{|l|}{$173 / 926$} & \\
\hline All causes & $87^{* * *}$ & 20.6 & $4 \cdot 2$ & $102 * * *$ & $39 \cdot 2$ & $2 \cdot 6$ & $24 * * *$ & $7 \cdot 8$ & $3 \cdot 1$ & $70^{* * *}$ & $41 \cdot 0$ & $1 \cdot 7$ \\
\hline Lung cancer & $39 * * *$ & $2 \cdot 5$ & $15 \cdot 6$ & $39 * * *$ & $4 \cdot 2$ & $9 \cdot 3$ & $11 * * *$ & $1 \cdot 0$ & $11 \cdot 0$ & $20 * * *$ & $4 \cdot 3$ & $4 \cdot 7$ \\
\hline Mesothelioma & 10 & - & - & 8 & - & - & 3 & - & - & 4 & - & - \\
\hline Asbestosis & 14 & 一 & - & 18 & - & - & 8 & - & 一 & 16 & - & - \\
\hline
\end{tabular}

$* * * p<0.001$.

for both age groups but, relative to expectation, those certified younger had the worse prognosis. At London the lung cancer rate was 16 times expectation for those certified before age 55 and nine times expectation for those certified when older; at Cardiff the rates were 11 and five times expectation respectively.

\section{Statistical significance of factors on excess mortality of men with asbestosis}

Several factors that might have been associated with the excess mortality rate have been examined and several of these have proved relevant. Possible interactions among the factors could result in the association with one factor appearing as an apparent association of a second factor. Analyses have been carried out to check on this possibility. The results were as follows:

(1) The factor with the largest association was the initial disablement benefit (table 7); after allowing for panel and age at certification this association was still significant $(p<0.001$ for all causes and for lung cancer).

(2) Age at certification had the second largest association with excess mortality (table 10) and, after allowing for initial benefit and panel, was significant $(p<0.001$ for all causes, $p<0.01$ for lung cancer). The younger the age at certification the higher the excess mortality.

(3) The difference between the two panels (table 6) was significant $(p<0.01$ for all causes, $p<0.05$ for lung cancer) after allowing for initial disablement benefit and age at certification. This difference was mainly in the groups awarded $10 \%$ or $20 \%$ benefit (table 7), indicated by a significant interaction between panel and benefit $(p<0.05)$ for lung cancer. Of the London cases, $37 \%$ were certified before 1966 compared with only $6 \%$ at Cardiff (table 3), and the prognosis of those certified before 1966 was worse than for those certified more recently (table 9). Making allowance for certification date reduced the difference between panels, which was significant only for all causes $(\mathrm{p}<0.05)$.

(4) After allowing for disablement benefit and panels the decline in death rate from all causes after 10 years from certification (table 6) was significant $(\mathrm{p}<0.05)$.

(5) Differences between occupation groups (table 8) and year of certification (table 9) were not statistically significant.

Loss of expectation of life of men with asbestosis The expectation of life of men aged 55 is $19 \cdot 1$ years. $^{?}$ If the excess death rates given in table 7 , combined over panels, operated on men certified at age 55 for the next 15 years and thereafter there was no excess death rate the effects would be as in table 11 . For men awarded $10 \%$ disablement benefit the expectation of life would be reduced by three years, for $20 \%$ benefit by five years, for $30 \%$ or $40 \%$ benefit by eight years, and for men awarded $50 \%$ or more benefit by 12 years. Taking account of the association of the excess death rate with age at certification, then for men certified at age 50, when the normal 
Table 11 Reduction in life expectation for men certified with asbestosis at age 55

\begin{tabular}{llc}
\hline $\begin{array}{l}\text { Disablement } \\
\text { benefit }(\%)\end{array}$ & $\begin{array}{l}\text { Life expectation } \\
\text { (years) }\end{array}$ & $\begin{array}{l}\text { Reduction } \\
\text { (years) }\end{array}$ \\
\hline None & $19 \cdot 1$ & - \\
10 & $15 \cdot 8$ & $3 \cdot 3$ \\
20 & $14 \cdot 4$ & $4 \cdot 7$ \\
30 or 40 & $11 \cdot 2$ & $7 \cdot 9$ \\
$>50$ & $7 \cdot 2$ & $11 \cdot 9$ \\
\hline
\end{tabular}

life expectation is 23 years, the reduction would be seven years for disablement benefit of $10 \%$ or $20 \%$ and eight years for $30 \%$ or $40 \%$ benefit. For men certified at age 60 , when the normal life expectation is 15 years, the reductions would be three and seven years respectively. All of the above reductions in life expectation could be underestimates because, although there was evidence of a decline in the excess death rates with time since exposure, the assumption that there would be no excess after 15 years is extreme.

\section{Comparison of observed and expected mortality for women with asbestosis}

Table 12 gives the results for the 21 women. This group was small, but there were excesses of deaths due to lung cancer and other cancers. Of the latter, two were of the gastrointestinal tract $(\exp =0.20$; $p<0.05$ ) and the other three of the liver, breast, and uterus.

\section{Discussion}

The observed mortality has been compared with that expected based on the death rates for England and Wales. There are at least two reasons why the observed and expected were not exactly comparable. Firstly, the deaths were investigated more thoroughly, usually with a necropsy, than most deaths occurring in the national population. Copies of death certificates are not kept in the panels' files and so in- formation was not available on the registered causes of death. There were a few deaths that might have been classified as due to carcinomatosis, but the necropsy showed a primary lung carcinoma; this accounts for some discrepancies between this paper and the preliminary report. ${ }^{5}$ Secondly, use of the national death rates may not be completely appropriate for the area covered by the two panels. Most cases from the Cardiff Panel were from South-west England, where the standardised mortality ratio (SMR) for lung cancer was 82, averaged over 1965, 1970, and 1973. In Greater London the SMR for lung cancer was 119. Men certified as suffering from asbestosis probably came mostly from urban areas, where the lung cancer rate is higher than in rural areas. As it was not possible to make the correct allowance for differences between areas the comparisons between the panels were the weakest parts of the study. For lung cancer the difference between panels was confined to those initially awarded $10 \%$ or $20 \%$ compensation and was not significant after allowing for year of certification.

There is little difference between the SMRs for all deaths for South-west England and Greater London so that the difference between panels for deaths from all causes, which was significant restricting the comparison to London cases certified after 1965 (observed/expected $=2.7$ ) and all Cardiff cases (observed/expected $=1.9$ ), was probably real, and the possibility of a diagnostic difference cannot be excluded.

Although there was some evidence of an excess risk due to other cancers for the London cases (tables 6 and 12), there was no such evidence for the cases at Cardiff and Swansea.

Smoking habits were known for $96 \%$ of the men. Smoking was not included in the analysis because only 32 men had never smoked; three of these died of lung cancer. It is established that non-smoking asbestos workers have an excess risk of lung cancer. ${ }^{8}$ The smoking habits of the certified asbestotic men

Table 12 Observed and expected mortality for London women

\begin{tabular}{|c|c|c|c|c|c|c|c|c|c|}
\hline & \multicolumn{9}{|c|}{ Time since certification } \\
\hline & $\begin{array}{l}0.5 \text { years } \\
\text { Obs }\end{array}$ & Exp & Obs/Exp & $\begin{array}{l}>5 \text { years } \\
\text { Obs }\end{array}$ & $\operatorname{Exp}$ & $O b s / E x p$ & $\begin{array}{l}\text { Total } \\
\text { Obs }\end{array}$ & Exp & Obs/Exp \\
\hline $\begin{array}{l}\text { No/subject-years } \\
\text { Cause of death }\end{array}$ & $21 / 99$ & & & $18 / 126$ & & & $21 / 225$ & & \\
\hline All causes & $3 *$ & 0.64 & $4 \cdot 7$ & $9 * * *$ & 1.47 & $6 \cdot 1$ & $12 * * *$ & $2 \cdot 11$ & $5 \cdot 7$ \\
\hline Lung cancer & $1 *$ & 0.02 & $50 \cdot 0$ & $1^{*}$ & 0.05 & $20 \cdot 0$ & $2 * *$ & 0.07 & $28 \cdot 6$ \\
\hline Mesothelioma & 0 & - & - & 0 & - & - & 0 & - & - \\
\hline Other cancers & $2 *$ & $0 \cdot 21$ & $9 \cdot 5$ & $3 * *$ & 0.40 & $7 \cdot 5$ & $5 * * *$ & 0.61 & $8 \cdot 2$ \\
\hline Asbestosis & 0 & - & - & 3 & - & - & 3 & - & - \\
\hline $\begin{array}{l}\text { Other causes (and } \\
\text { no information) }\end{array}$ & 0 & $0 \cdot 41$ & $0 \cdot 0$ & 2 & $1 \cdot 02$ & $2 \cdot 0$ & 2 & $1 \cdot 43$ & $1 \cdot 4$ \\
\hline
\end{tabular}

$* \mathrm{p}<0.05 \quad * * \mathrm{p}<0.01 \quad * * * \mathrm{p}<0.001$ 
were compared with the population of Britain taking account of age and period. ${ }^{9}$ Of those with known smoking habits, $5 \%$ had never smoked compared with $10 \%$ expected, $30 \%$ were ex-smokers compared with $20 \%$ expected, and $65 \%$ were current smokers compared with $70 \%$ expected. About $60 \%$ of the cigarette smokers had at some time smoked 15 or more cigarettes a day, and this percentage is slightly less than the national average. The deficit of those who had never smoked is in accord with evidence that asbestos workers who smoke have more signs of asbestosis than their non-smoking colleagues. ${ }^{1011}$ As the certified cases contained a higher proportion who had smoked than the general population this means that part of the observed excess of lung cancer can be attributed to smoking but, as the national death rates are calculated on the whole population who mainly smoke, the bias will be small.

The results of this study are in general agreement with previous studies. ${ }^{14}$ These studies covered a shorter period but a wider range of panels. Over the period of these two studies the four panels included $85 \%$ of the cases in Britain. In the study reported in this paper the London, Cardiff, and Swansea Panels included almost $40 \%$ of the cases.

Mortality from all three asbestos-related diseases -asbestosis, mesothelioma, and lung cancerincreased with percentage disability, which is assessed on a combination of several signs and symptoms. Coutts et al ${ }^{12}$ investigated cases certified by the London Panel between 1968 and 1974 and found that mortality from all causes increased with the profusion of small opacities on the chest radiograph, but found no association between mortality from lung cancer and small opacities. The method of using several features to assess severity of the disease thus gives a better indication of overall prognosis.

The excess death rates result in a loss of expectation of life which is, on average, three years for the lowest rate of disablement benefit, and more for higher rates of benefit and for men certified at younger ages. The award of benefit is for disability during life and does not take account of any reduction in life expectation. Thus disablement benefit cannot be regarded as full compensation for asbestosis.
I am grateful to Dr R G B Williamson, Dr T J G Phillips, Mr A C Hutchinson, and Mr D M Blythe (DHSS) for arranging for the data to be made available; to Dr W R Parkes, Dr J P Lyons, and Dr G Whyte of the London, Cardiff, and Swansea Pneumoconiosis Medical Panels and their staffs for their co-operation; and to Mrs $\mathbf{J}$ Hext (Health and Safety Executive) and Miss C Exall (MRC Pneumoconiosis Unit) who extracted the data. The study was initiated by Dr J C Gilson, formerly director of MRC Pneumoconiosis Unit, and I am especially grateful to him and to Dr P C Elmes, the present director, for all their perseverance over several years in ensuring that the study was carried out and for their encouragement throughout.

\section{References}

${ }^{1}$ McVittie JC. Asbestosis in Great Britain. Ann NY Acad Sci $1965 ; 132: 128-38$.

${ }^{2}$ Department of Health and Social Security. Pneumoconiosis and related occupational diseases. London: HMSO, 1979. (NI 226.)

${ }^{3}$ Department of Health and Social Security. Social security statistics 1977. London: HMSO, 1979.

${ }^{4}$ Department of Employment and Productivity: HM Factory Inspectorate. Problems arising from the use of asbestos. London: HMSO, 1968.

${ }^{5}$ Berry G. The prognosis following certification with asbestosis in the United Kingdom. In: Wagner JC, ed. Biological effects of imineral fibres. Lyon: International Agency for Research into Cancer, 1980;603-8. (Scientific Publications No 30.)

${ }^{6}$ Case RAM, Lea AJ. Mustard gas poisoning, chronic bronchitis, and lung cancer. Br J Prev Soc Med 1955; 9:62-72.

'Office of Population Censuses and Surveys. Life tables: the Registrar General's decennial supplement for England and Wales 1970-2. London: HMSO, 1979.

${ }^{8}$ Selikoff IJ, Hammond EC. Asbestos and smoking. JAMA 1979;242:458-9.

${ }^{9}$ Lee PN, Wilson MJ, comps. Statistics of smoking in the United Kingdom. 7th ed. London: Tobacco Research Council, 1976.

${ }^{10}$ Berry G, Gilson JC, Holmes S, Lewinsohn HC, Roach SA. Asbestosis: a study of dose-response relationships in an asbestos factory. Br J Ind Med 1979;36:98-112.

${ }^{11}$ Rossiter CE, Harries PG. UK naval dockyards asbestosis study: survey of the sample population aged 50-59 years. Br J Ind Med 1979;36:281-91.

${ }^{12}$ Coutts II, Gilson JC, Kerr IH, Parkes WR, TurnerWarwick M. Mortality in asbestosis in relation to initial radiographic appearance. Thorax 1980;35:235-6. (Abstract.) 